Специфика формирования досуговой культуры студенческой молодежи с OB3 также включает интенсивное применение культуротворческих технологий в процессе изучения иностранного языка для развития творческого потенциала личности. В процессе исследования доказано, что формирование досуговой культуры студенческой молодежи с ОВ3 на основе использования потенциала иностранного языка будет эффективным при комплексном воздействии на личность, при активной ее включённости в международную социально-культурную деятельность, осуществляемую через образовательную и творческую практику студенческой молодежи с ОВ3 в ходе межкультурного общения и взаимодействия.

$$
* * *
$$

1. Апанасюк, Л.А., Киреева, И.А. Технология межкультурного сотрудничества: теория и методология: монография. - Тольятти. - Изд-во ВУиТ,2012. - 156 с.

2. Григорьева, Е.И. Генезис и эволюция народных промыслов и ремесел (региональный историкокультурологический аспект): монография. - Тамбов: Изд-во ТГУ им. Г.Р. Державина, 1999. - 287 с.

3. Джуринский, А.Н. Сравнительная педагогика: Учебное пособие. -М.: Изд. центр «Академия», $1998.176 \mathrm{c.}$

4. Дуликов, В.3. Социальные аспекты культурно-досуговой деятельности за рубежом: учебное пособие. - М.: МГУКИ, 1999. - 109 с.

5. Киселева, Т.Г., Красильников, Ю.Д. Основы социально-культурной деятельности. - М.: Изд-во Московского государственного университета культуры, 1995. - 136 с.

6. Тер-Минасова, С.Г. Язык и межкультурная коммуникация / С.Г. Тер- Минасова. - М.: «Слово», 2010. $-261 \mathrm{c}$.

\title{
Карабанова О.P. \\ Основные направления совершенствования культуры межнационального общения в воинском коллективе
}

Филиал Военного учебно-научного ичентра Военно-воздушных сил «Военно-воздушная академия» в г. Челябинске (Россия, Челябинск)

doi: 10.18411/lj-04-2021-154

\section{Аннотация}

В статье поднимается проблема межнационального общения, подчеркивается ее актуальность и важность на современном этапе развития нашего общества, в российской армии в частности. Автор акцентирует внимание на основных направлениях совершенствования культуры межнационального общения в воинском коллективе, раскрывает их суть и описывает применение в учебно-воспитательном процессе в условиях военного вуза.

Ключевые слова: межнациональное общение, этническая группа, курсант.

\section{Abstract}

The article raises the problem of interethnic communication, emphasizes its relevance and importance at the present stage of development of our society, in the Russian army in particular. The author focuses on the main directions of improving the culture of interethnic communication in the military team, reveals their essence and describes their application in the educational process in a military University.

Keyword: international communication, ethnic group, cadet.

На современном этапе развития нашего общества в связи с политической нестабильностью, социально-экономическим и нравственным кризисом стало все больше проявляться межнациональное расслоение, национальная нетерпимость людей друг к другу. В этой связи проблема культуры межнационального общения становится 
одной из самых актуальных в нашем многонациональном государстве, в том числе и в российской армии.

Решению данной проблемы посвящена Стратегия государственной национальной политики России на период до 2025 года, направленная на всестороннее сотрудничество народов Российской Федерации, развитие их национальных культур [1].

Важную роль в решении данной проблемы имеет и система военного профессионального образования, оказывающая значительное влияние на обеспечение организации учебно-воспитательного процесса, культуры межнационального общения военнослужащих в частности.

Ежегодно в военный вуз поступают молодые люди из разных уголков нашей многонациональной страны - представители различных этнических групп. Некоторые ребята имеют искаженную информацию о национально-психологических особенностях других этнических групп, так как большинство из них проживает и общается преимущественно с лицами одной национальности. Сложившиеся стереотипы и установки по отношению к различным национальностям прочно закрепились в семье и социуме, поэтому возникают проблемы по выстраиванию межнациональной коммуникации при прохождении военной службы и обучении в военном вузе.

Профессорско-преподавательскому составу, офицерам курсового звена, психологам необходимы не только глубокие и прочные знания по военной педагогике и психологии, но и умение организовать учебно-воспитательный процесс в активной поликультурной среде, направленный на гармонизацию межнациональных, межкультурных отношений на основе уважения самобытной национальной культуры, традиций, проявлении межэтнической толерантности.

Обратим внимание на основные направления совершенствования культуры межнационального общения в воинском коллективе.

В первую очередь, в рамках сплочения воинских коллективов необходимо проводить военно-пропагандистскую работу. Рассказывать о героических боевых традициях наших Вооруженных Сил, многонациональном составе нашей страны, традициях дружбы и взаимопомощи граждан России, достижений братских республик, их национальных героях и др. Максимально использовать для этих целей занятия по общественно-государственной подготовке, привлекать военнослужащих различных национальностей с выступлениями о своем родном крае, исторических событиях, национальной культуре.

В программу культурно-досуговой работы целесообразно включать просмотр художественных фильмов, чтение национальной литературы, акцентируя внимание на уважении этноса малых народностей России, сотрудничестве и войсковом товариществе разных национальностей, искоренении нарушений уставных правил взаимоотношений.

Спортивно-массовую работу можно разнообразить различными спортивными соревнованиями по национальным играм и видам спорта тех национальностей, представители которых обучаются в военном вузе.

Д.Е. Матвеев [2] предлагает особое внимание обратить на учебные дисциплины, обеспечивающие формирование культуры межнационального общения военнослужащих. По мнению автора, одно из решений данной проблемы - включение этнокультурного компонента в содержание учебных дисциплин и разработка спецкурса «Культура межнационального общения» [2].

Действительно, дисциплины общегуманитарного и социально-экономического цикла «Философия», «Политология», «Отечественная история», «Культурология», «Социология» окажут большую помощь при формировании мировоззренческих позиций, овладении знаниями об исторических, политических, социальных явлениях 
общества и личности, международного взаимодействия, а также роли различных факторов в развитии многообразия национальных культур и цивилизации.

Большие возможности в совершенствовании межнационального общения имеет «Культурология», так как является основой в воспитании духовно-нравственных ценностей, формирует в будущих офицерах эстетические, нравственные качества, национальной субкультуры в том числе.

Учебные предметы «Военная психология», «Военная педагогика» имеют большое значение в воспитании, так как служат научной основой подготовки будущего офицера к воспитанию культуры межнационального общения военнослужащих, «содержат ценный теоретический материал, дает курсантам знания по этнокультуре» [3].

Данные предметы расширяют и формируют знания о психике, человеке как личности, его индивидуальных особенностях, межчеловеческой толерантности; обучают выстраиванию бесконфликтной коммуникации в различных социокультурных условиях. Важно только преподносить эти знания и с позиции этнопсихологии.

Следующее направление совершенствования межнационального общения мы видим в формировании профессиональной идентичности военнослужащих.

Офицеры в первую очередь должны быть образцом для подражания, показывать пример высоконравственного отношения к военнослужащим разных национальностей. Уважение к национальному достоинству личности, национальным особенностям, истории и культуре различных этнических групп - принципы, по которым строится все дальнейшее воспитание и обучение в военном вузе.

Именно от качества подготовки офицерских кадров в современных условиях, военного профессионализма, верности и преданности национальным традициям России зависит боеготовность и боеспособность ее Вооруженных сил [4, с. 57].

Также одним из важных направлений совершенствования культуры межнационального общения является и психолого-педагогическая подготовка.

Преподавателям, офицерам курсового звена рекомендуется постоянно повышать психолого-педагогические знания о национальных особенностях военнослужащих, их традициях, культуры, религии, современной общественно-политической жизни.

Особое внимание необходимо обращать на первичное формирование учебных групп. Продуманное их комплектование специалистами психологической службы на этапе зачисления в военный вуз - залог хорошего морально-психологического климата в воинском коллективе. Необходимо заботиться, чтобы в подразделениях не преобладали представители одной национальности, вдумчиво подходить к подбору, расстановке и воспитанию сержантского состава подразделения.

В процессе адаптации ребята группируются чаще всего по земляческому принципу. И если своевременно не наладить работу с микрогруппами, то в дальнейшем могут появиться конфликты между военнослужащими на национальной почве.

Индивидуальную и групповую работу следует проводить, зная национальнопсихологические черты этнических групп. Необходимо изучать социальнополитическую ситуацию в регионах и республиках, откуда призваны курсанты, основные национальные традиции и обычаи, привычки, черты и свойства национального характера. Поэтому актуальной является военно-политическая работа по воспитанию толерантности. Разделяя мнение С.И. Фишера, подчеркнем, что под толерантностью мы понимаем «специфическую психологическую установку, ориентирующую на уважительное восприятие чужой этнической, религиозной самостоятельности, культуры, нравственных ценностей, мировоззренческих убеждений, стремление к мирному сосуществованию и взаимопониманию» $[5$, с. 56].

Еще одним важным направлением совершенствования культуры межнационального общения является тесное взаимодействие офицеров курсового звена со специалистами психологической службы. Проведенная диагностика личностных особенностей курсантов, межличностных и неуставных взаимоотношений в воинском 
коллективе, своевременная выдача рекомендаций по дальнейшей работе и впоследствии реализация их на практике повысит результаты воспитательной работы.

Совместно с психологами курсовой офицер должен анализировать совместимость, сплоченность и разобщенность в воинском коллективе, реагировать на выявленные негативные проявления формальных и неформальных лидеров, курсантов, оказывающихся в психологической изоляции, разделении членов коллектива на различные микрогруппы по национальному и другим признакам.

Целесообразно периодически оценивать уровень взаимоотношений членов коллектива, как по «горизонтали», так и по «вертикали», помнить, что психологическую основу сплоченности воинского коллектива составляет именно положительный характер взаимоотношений командира и коллектива, командира и отдельных военнослужащих, военнослужащих между собой, складывающийся в процессе совместной служебной и повседневной деятельности.

Необходимо помнить, что активная совместная деятельность военнослужащих способствует формированию культуры межличностного взаимодействия и межнационального общения, формирует уважение к историческому прошлому и настоящему в культуре наций и народностей России.

Мы рассмотрели основные направления совершенствования культуры межнационального общения как одного из важнейших направлений в государственной политике нашей страны, в российской армии в частности.

Реализация данных направлений на практике позволит, по нашему мнению, расширить взаимодействие между военнослужащими различных национальностей, обеспечит готовность к жизнедеятельности и выполнению служебных задач по предназначению в любом многонациональном воинском коллективе. А также будет содействовать сохранению и приумножению национального и культурного наследия этнических групп, их национального характера, самобытных традиций, что в свою очередь укрепит межнациональные связи, сотрудничество и предотвратит идеологическое расслоение между народностями России и на международной арене.

$$
* * *
$$

1. У Указ Президента РФ от 19.12.2012 № 1666 «О стратегии государственной национальной политики Российской Федерации на период до 2025 года» https: /base. garant.ru/ 70284810/ (дата обращения 27.03.2021г.).

2. Матвеев Д.Е. Реализация спецкурса как условие формирования готовности будущего офицера к воспитанию культуры межнационального общения военнослужащих / Мир науки, культуры, образования. 2013. № 2 (39). С. 8-10.

3. Барабанщиков А.В. Педагогическая культура преподавателя высшей военной школы. М.: Воениздат. $1985.159 \mathrm{c.}$

4. Блягоз Н.Ш. Проблематика формирования культуры межнационального общения /Евразийский союз ученых. 2020. № 10-4 (79). С. 56-58.

5. Фишер С.И. Задачи военно-политических органов МО РФ по формированию культуры межнационального общения курсантов высших военных учебных заведений как показателя этнической толерантности / Гуманитарный вестник Военной академии ракетных войск стратегического назначения. 2019. № 3 (16). С.51-67.

\section{Комащук К.И., Евтушенко В.И. \\ Особенности производства по делам об административных правонарушениях в сфере антиалкогольного законодательства}

Белгородский государственный национальный исследовательский университет doi: 10.18411/lj-04-2021-155

(Россия, Белгород)

\section{Аннотация}

Настоящая статья направлена на рассмотрение и анализ особенностей производства по делам об административных правонарушениях в сфере 